\title{
Loss of susceptibility as a novel breeding strategy for durable and broad-spectrum resistance
}

\author{
Stefano Pavan - Evert Jacobsen • \\ Richard G. F. Visser · Yuling Bai
}

Received: 1 April 2009/Accepted: 31 July 2009/Published online: 15 August 2009

(C) The Author(s) 2009. This article is published with open access at Springerlink.com

\begin{abstract}
Recent studies on plant immunity have suggested that a pathogen should suppress induced plant defense in order to infect a plant species, which otherwise would have been a nonhost to the pathogen. For this purpose, pathogens exploit effector molecules to interfere with different layers of plant defense responses. In this review, we summarize the latest findings on plant factors that are activated by pathogen effectors to suppress plant immunity. By looking from a different point of view into host and nonhost resistance, we propose a novel breeding strategy: disabling plant disease susceptibility genes (S-genes) to achieve durable and broad-spectrum resistance.
\end{abstract}

Keywords Effector - Effector target .

Effector-triggered susceptibility .

Recessive resistance $\cdot$ Susceptibility genes

S. Pavan · E. Jacobsen · R. G. F. Visser · Y. Bai ( $\square)$

Graduate School Experimental Plant Sciences,

Wageningen UR-Plant Breeding, Droevendaalsesteeg 1, 6708 PB Wageningen, The Netherlands

e-mail: bai.yuling@wur.nl

\section{S. Pavan}

Department of Agroforestry, Environmental Biology and Chemistry, Section of Genetics and Plant Breeding, University of Bari, Via Amendola 165/A, 70126 Bari, Italy

\section{Introduction}

Though resistance and susceptibility are opposite sides of the same coin, most studies have focused for a long time on the resistance side in search for plant resistance genes (R-genes) and other defense genes. In 2002, when PMR6 was discovered as a gene coding for a susceptibility factor for promoting growth of powdery mildews, Eckardt (2002) questioned "Are there plant genes that are required for susceptibility to certain pathogens?" In 2005 , based on the unique forms of resistance conferred by loss of function in genes like Mlo, PMR6 and eIF4E, De Almeida Engler et al. (2005) suggested to exploit susceptibility genes as an alternative in breeding for nematode resistance. Nowadays, the field is rapidly moving toward identification of plant factors targeted by pathogen effectors and elucidation of mechanisms controlling plant disease susceptibility. Ultimately, a better understanding of the molecular basis of plant disease susceptibility can be applied in breeding for resistance against a wide spectrum of pathogens. This review, by highlighting recent studies on effectortriggered susceptibility, proposes a novel breeding strategy: exploitation of plant susceptibility genes (S-genes) for durable and broad-spectrum resistance.

\section{Disease susceptibility genes (S-genes)}

Plants are exposed to a tremendous number of potential pathogens. Many plant pathogens can infect 
only a limited number of plant species that are called hosts to the given pathogen. To exploit a plant as a host, pathogens have to overcome plant defense mechanisms ranging from preformed passive barriers (e.g. physical barriers such as the cuticle of leaves) to induced defense reactions (e.g. Heath 2000; ThordalChristensen 2003; Niks and Marcel 2009). The front line of the induced defense is triggered by pathogenassociated molecular patterns (PAMPs), also termed as PAMP-triggered immunity (PTI). PAMPs are generally conserved compounds (like chitin in fungi and flagellins of bacteria), and PTI is induced by all invading pathogens (Bittel and Robatzek 2007; Boller and He 2009; Jones and Dangl 2006). Thus, suppression of PTI is required as the first step for a pathogen to alter a plant's status from a nonhost into a host. For adapted pathogens, the suppression of PTI is achieved by the secretion of pathogen effectors to manipulate host cell functions (Jones and Dangl 2006; van der Hoorn and Kamoun 2008).

In the field of plant-microbe interactions, the study on how effectors suppress PTI to establish effectortriggered susceptibility (ETS) has moved to the center stage (Hoefle and Hückelhoven 2008). Emerging evidence suggests that the primary function of pathogen effectors is to suppress plant innate immunity by interacting with specific host proteins (effector targets) (Nomura et al. 2005; Jones and Dangl
2006; Chisholm et al. 2006; Kamoun 2007; Van der Hoorn and Kamoun 2008). Not surprisingly, most effector targets play a positive role in plant defense machinery, like defense-signaling components (Chisholm et al. 2006; Bittel and Robatzek 2007; Speth et al. 2007; Fig. 1). For example, the effector HopAI1 of Pseudomonas syringae suppresses PTI by inactivating Arabidopsis MPK 3 and MPK6 (mitogen-activated protein kinases), two key components of the plant immune response-signaling cascade (Zhang et al. 2007).

However, some pathogen effectors suppress plant innate immunity by activating effector targets that function as negative regulators of the plant immunity system. In principle, knocking out such an effector target would release the suppression of plant defense and lead to resistance (Fig. 1). More and more examples of this group are being identified (Tables 1,2). One of the well-characterized examples is the transmembrane MLO protein, which negatively regulates PEN gene-associated disease resistance to powdery mildews (Bhat et al. 2005; Panstruga 2005; Hardham et al. 2007; our unpublished data). In barley and Arabidopsis, loss-of-function mutations in Mlo result in efficient preinvasion resistance to adapted powdery mildews (Büschges et al. 1997; Piffanelli et al. 2004; Humphry et al. 2006). Recently, it has been shown that the tomato recessive allele ol-2, conferring

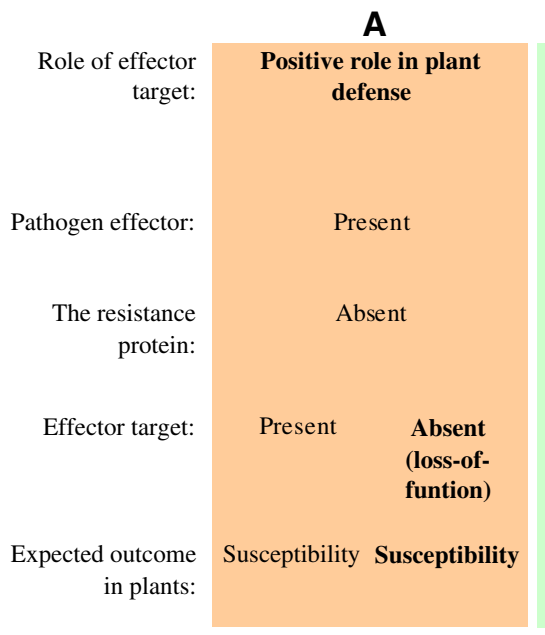

Fig. 1 Comparison on effector targets with positive or negative roles in plant defense to demonstrate how to obtain resistance by knocking out susceptibility gene. Panel a shows that, in the absence of resistance protein, both presence and absence of the effector target (with a positive role in plant

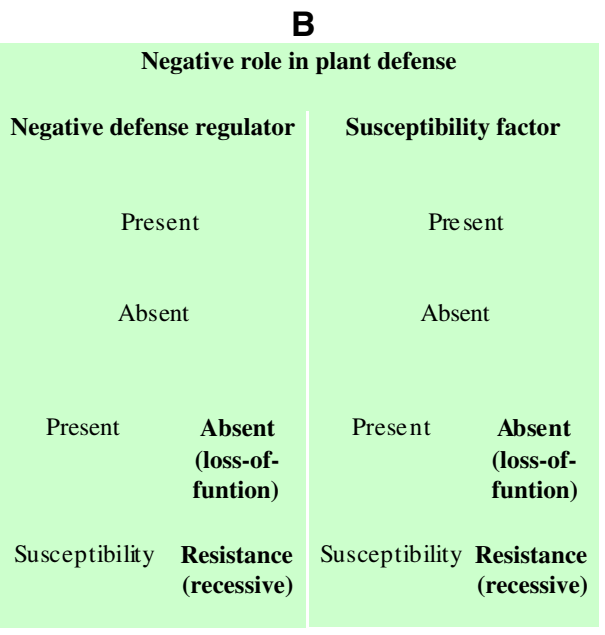

defense) lead to susceptible plants. Panel b demonstrates that, in the absence of resistance protein, presence of the effector target (with a negative role in plant defense) leads to susceptible plants and that knocking out the effector target leads to resistant plants 


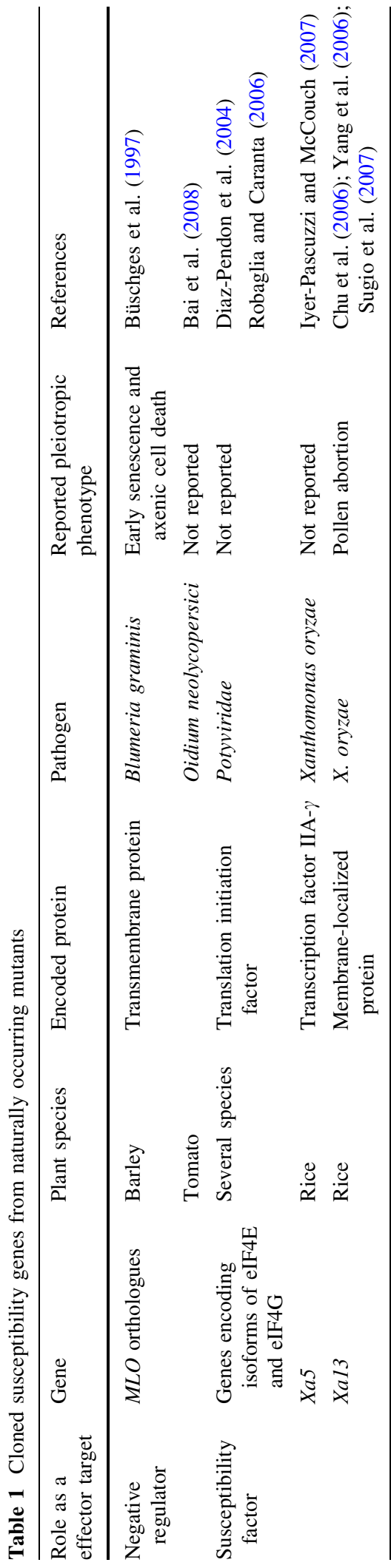

resistance to the powdery mildew fungus Oidium neolycopersici, is also caused by a null mutation of the tomato SlMlol (Bai et al. 2008; Pavan et al. 2008).

In addition to the suppression of PTI, pathogen effectors may promote disease by activating effector targets that function as susceptibility factors, like plant factors that are required by the pathogen for its growth and development (Fig. 1). Examples are isoforms of eIF4E and eIF4G functioning as translation factors for potyvirus replication and infection (Diaz-Pendon et al. 2004; Robaglia and Caranta 2006). Interestingly, all characterized recessive resistances to viruses originate from mutations in isoforms of eIF4E and eIF4G, two components of the translation initiation complex (Kang et al. 2005b; Albar et al. 2006; Robaglia and Caranta 2006). The mechanism leading to resistance is likely due to the lack of interaction between the viral effector protein $\mathrm{VPg}$ and the translation initiation complex (Robaglia and Caranta 2006).

In this review, we refer to genes required for susceptibility as disease susceptibility genes (S-genes), such as genes coding for effector targets that function as negative defense regulators or susceptibility factor (Fig. 1). The term of plant S-gene was first introduced in the review of Eckardt (2002). Genetically, S-genes can be defined as dominant genes whose impairment will lead to recessive resistance. Recessive resistances have been known for many years (e.g. Stubbs et al. 1983). For example, the first reported resistance gene was identified by Biffen in 1905, which is recessively inherited and confers resistance to wheat yellow rust (Puccinia striiformis) (Singh and Singh 2005). One of the recently reported recessive resistance genes is the $r p s G Z$ gene, which is effective against all races of the barley stripe rust $P$. striiformis f.sp. hordei (Yan and Chen 2006). Only few recessive resistance genes have been characterized for their role in plant disease establishment (Table 1). It is intriguing to know whether natural recessive resistances result from lossof-function mutations of S-genes that code for effector targets. With increasing interest in the research topic on suppression of PTI and establishment of ETS, a considerable amount of potential S-genes has been recently identified via different experimental approaches (Table 2). Proteins encoded by S-genes have been shown or predicted to be activated by effectors for ETS. The challenge is how to exploit S-genes, in complementary to R-genes, in plant breeding for durable and broad-spectrum resistance. 


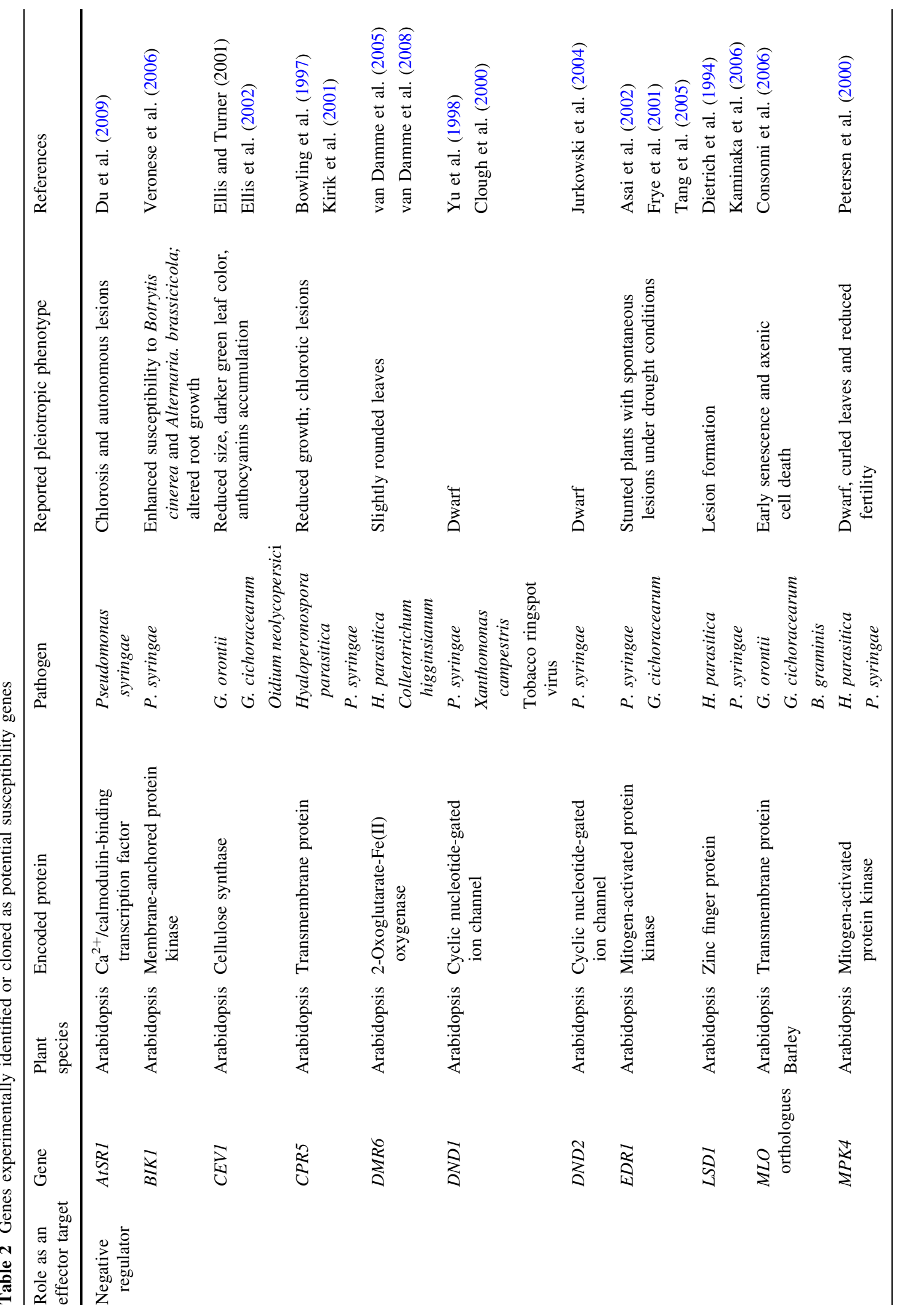




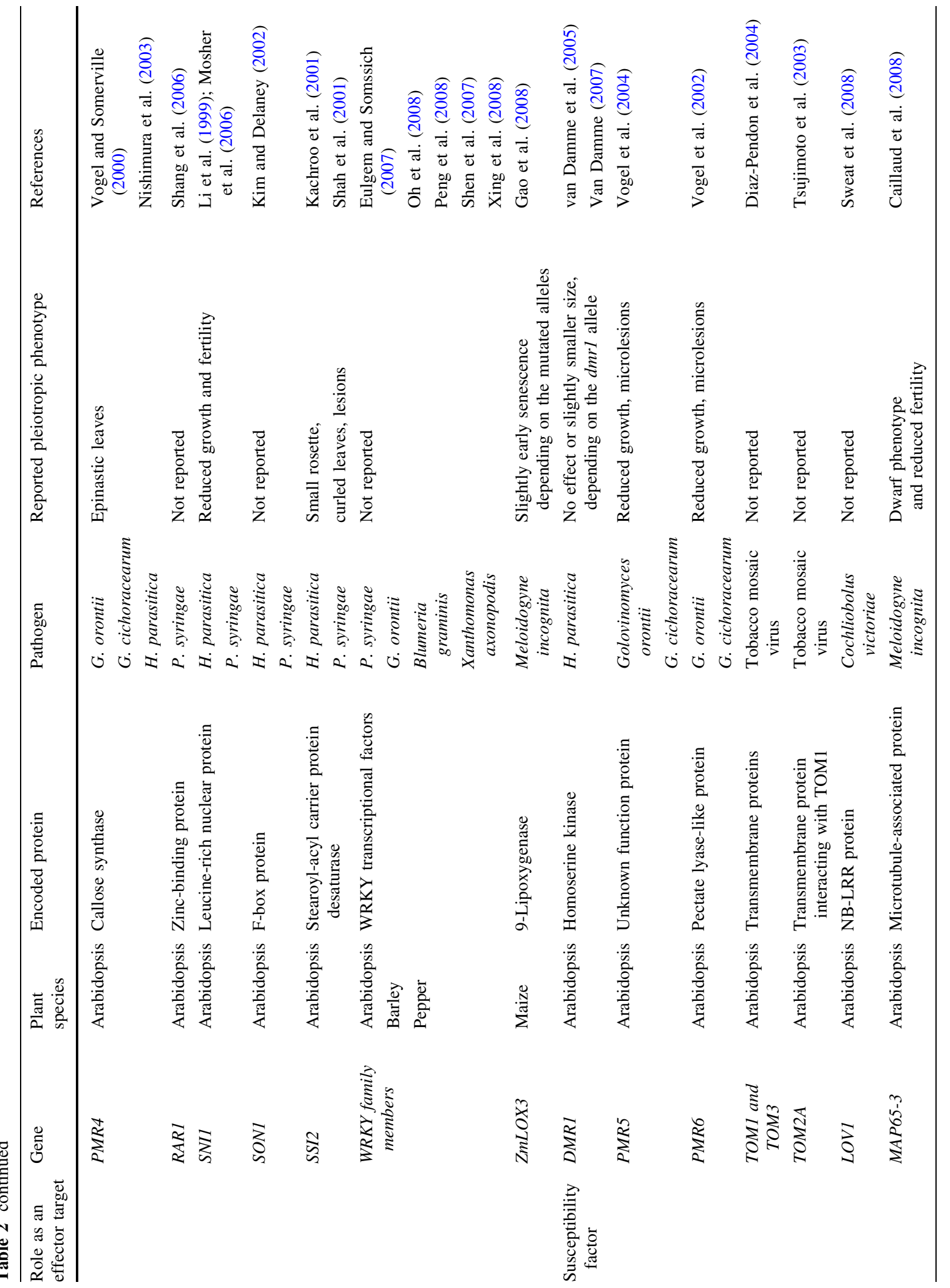




\section{R-genes and S-genes}

To combat the pathogens that succeed in establishment of ETS, host plants have evolved a race-specific immunity, a well-described host resistance mechanism that is governed by dominant R-genes (e.g. Speth et al. 2007; Hoefle and Hückelhoven 2008; Wladimir et al. 2008). Hundreds of R-genes have been cloned and most of them encode proteins with an N-terminal nucleotide-binding (NB) site and C-terminal leucinerich repeats (LRRs) (Takken et al. 2006). R-genes encode proteins that recognize pathogen effectors to establish effector-triggered immunity. This recognition triggers a cascade of defense responses, mediated by a complex-signaling network in which plant hormones, like salicylic acid (SA) and jasmonic acid (JA), play a major role and the resistance is manifested as localized hypersensitive response at the site of infection (Robert-Seilaniantz et al. 2007; Bruce and Pickett 2007; Bari and Jones 2009). It is generally assumed that most R-proteins function in a tripartite module (van der Hoorn et al. 2002), where the R-protein guards a specific effector target (also known as virulence target), and in doing so can detect modifications induced by the pathogen effector. Effector targets required for R-protein function are recently categorized into two subgroups, decoy and guardee (Van der Hoorn and Kamoun 2008). An effector target is termed as a decoy if it has no function in host defense or susceptibility in absence of its cognate R-protein. In the decoy model, operative effector targets play a role in enhancing pathogen fitness in plants lacking the R-protein. A gene is considered an S-gene if it codes for the operative target that plays a negative role in plant defense (Fig. 1). One example is the pepper upa20 gene that encodes a regulator of cell enlargement (Zhou and Chai 2008). In susceptible plants, AvrBs3, which is a type-III effector secreted by Xanthomonas campestris pv vesicatoria, mimics the eukaryotic transcription factor to activate upa20 gene to promote disease (Kay et al. 2007). In resistant plants, AvrBs 3 also activates the promoter of the pepper $B s 3$ gene (promoter of the $B s 3$ gene $=p B s 3$ ), which leads to the specific expression of the R-gene $B s 3$ and disease resistance. Obviously, upa20 is an S-gene, of which loss-of-function mutants would lead to resistance in plants lacking the $B s 3$ gene. $p B s 3$ is regarded as a decoy that is required for the R-gene Bs3 to trap AvrBs3 for resistance (Van der
Hoorn and Kamoun 2008; Zhou and Chai 2008). A guardee is used to term an effector target that, upon attack by a pathogen effector, enhances pathogen fitness in plants absent for the R-protein and triggers innate immunity in plants carrying the R-protein (Van der Hoorn and Kamoun 2008). Genes coding for guardees that play a negative role in plant defense can also be categorized as S-genes (Fig. 1). In summary, in the R-gene network, both operative targets and guardees are considered as products of S-genes if they play a negative role in plant defense as presented in Fig. 1.

The above described concept on effector-triggered immunity, which is activated by the recognition of pathogen effectors by plant R-proteins, is mainly based on findings obtained from plant interactions with biotrophic pathogens. For necrotrophic pathogens, host-specific-toxins are defined as pathogen effectors that induce toxicity and promote disease only in host species (Friesen et al. 2008). It is well-known that host-specific-toxins are host selective because they are typically active only in plants that serve as hosts for the pathogens (Wolpert et al. 2002). As a mirror image of effector-triggered immunity of biotrophic pathogen, the necrotrophic pathogen produces an effector that is recognized by a host receptor to trigger susceptibility (Friesen et al. 2008). Thus, plant genes coding for host receptors that are recognized by host-specific-toxins of necrotrophic pathogens are $\mathrm{S}$-genes. One example is the Arabidopsis LOVI geneconferring susceptibility to Victorian blight caused by Cochliobolus victoriae. The LOVI gene is an unusual finding of S-genes as it encodes a NB-LRR protein (Sweat et al. 2008), which is the largest protein family of R-proteins (Takken et al. 2006). Thus, the identification of $L O V I$ provokes a potential cross-link between plant $\mathrm{R}$ - and S-genes, suggesting that an $\mathrm{R}$-gene-conferring resistance to one pathogen also can confer susceptibility to another pathogen.

\section{Nonhost-like resistance}

For a long time, resistance conferred by loss of function of the barley Mlo gene has been considered as a unique type of plant immunity (Schulze-Lefert and Vogel 2000; Elliot et al. 2002; Hückelhoven 2005). Only recently, the comparison between nonhost resistance and mlo-based immunity in barley and 
Arabidopsis has lead to the conclusion that mlo-based resistance and nonhost resistance are "two faces of the same coin" (Humphry et al. 2006), as both types of resistance share analogous features like prehaustorial resistance mechanisms to powdery mildews (Trujillo et al. 2004; Ellis 2006). Besides, mlo-based resistance requires all the three described $P E N$ genes for nonhost resistance in Arabidopsis and the Ror2 genes (homo$\log$ of PEN1) in barley (Consonni et al. 2006; Humphry et al. 2006; Hardham et al. 2007). It has been demonstrated that mutations in these genes that affect nonhost resistance to powdery mildews compromise mlo-based resistance and vice versa (Consonni et al. 2006; Humphry et al. 2006; Hardham et al. 2007; Lipka et al. 2005; 2008). Thus, the absence of the key host protein (MLO) appears to convert a compatible interaction between an adapted powdery mildew and its respective host plant into an incompatible interaction having similar molecular mechanisms of nonhost resistance (Humphry et al. 2006).

The functional characterization of S-genes (Tables 1,2) has revealed that they encode proteins that are required by pathogens either for their growth process on the parasitized plant or for negative regulation of plant defense responses. These two events are indispensable for would-be pathogens to establish and maintain the infection process in plants. Consequently, the loss of function of such S-genes is expected to result in resistance against the pathogen. It has been shown (Tables 1,2 ) that such resistance can be effective even towards different, unrelated, pathogens. Moreover, when tested against different genetic variants of a pathogen, it has been often proven to be race nonspecific (Stein and Somerville 2002; Bai et al. 2005; Kang et al. 2005a). Little information is available relative to the durability of resistances conferred by loss of function of S-genes. However, resistances conferred by mutations of Mlo in barley and $e I F 4 E$ in pepper are still effective in the field after more than 30 and 50 years from their introduction in agriculture, respectively (Lyngkjaer et al. 2000; Kang et al. 2005a). Thus, loss of susceptibility has the potential to result in resistance that shares the "hallmarks of nonhost resistance" (Humphry et al. 2006): durability and broad-spectrum. In this review, we refer to mlo-based resistance as nonhost-like resistance defined as durable and broadspectrum resistance with similar defense mechanisms underlying nonhost resistance.

\section{S-genes in breeding for nonhost-like resistance}

In spite of promoting pathogen proliferation and disease establishment, S-genes have not been excluded by evolution. Evidence suggests that certain S-genes, besides being involved in plant-pathogen interactions, are required for the correct functioning of other important aspects of plant physiology. For example, the rice $\mathrm{Xa13}$ gene is required for both the growth of bacteria $X$. oryzae and plant pollen development (Chu et al. 2006). The dual function of such S-genes provides a unique opportunity for exploring the functional overlap between signal pathways for plant developments and pathogeninduced susceptibility.

Loss of function of S-genes, which encode for susceptibility factors, does not alter normal plant development. Few S-genes belonging to this category (Table 1) have been successfully employed in cultivation, which include resistance conferred by lossof-function mutations of Xa5, Xal3 and $e I F 4 G$ in rice; and $e I F 4 E$ in many crops including barley, pepper, lettuce, melon and pea (Candresse et al. 2002; Nicaise et al. 2003; Gao et al. 2004a, b; Kang et al. 2005a; Morales et al. 2005; Nieto et al. 2006; IyerPascuzzi and McCouch 2007; Rakotomalala et al. 2008; Tyrka et al. 2008). While, loss-of-function mutations of genes encoding negative regulators are in many cases accompanied by adverse pleiotropic effects due to constitutive defense activation, such as reduced growth and lesion-mimic phenotypes (Table 1). It has been reported that the extent of pleiotropic effects depends considerably on the environmental conditions as well as on plant species. For example, early senescence-like leaf chlorosis has been reported to occur in barley mlo mutants under certain conditions, while, no obvious pleiotropic phenotypes have been discovered yet in tomato mlo mutants (Bai et al. 2008). Although pleiotropic effects have been reported together with barley mlo mutants (Büschges et al. 1997), mlo resistance is by far the most used powdery mildew resistance source in spring barley grown in Europe (Lyngkjaer et al. 2000). The maize lox3-4 mutant, carrying a true null allele of the $Z m L O X$ gene, showed slightly shorter plants with earlier senescence comparing with the near-isogenic wild types. Throughout all stages of plant development, no other visible abnormalities were observed in lox3-4 mutants, suggesting the 
potential use of the S-gene, $Z m L O X$, in breeding for nematode resistance (Gao et al. 2008).

\section{Future perspectives}

The mlo mutant was originally discovered in barley more than 60 years ago and it was considered as a unique form of resistance in barley. The identification of mlo mutants in other plant species including Arabidopsis, tomato and most probably also pea and grape showed that it is more common in nature than previously anticipated (Consonni et al. 2006; Fondevilla et al. 2006; Bai et al. 2008; Feechan et al. 2008). Till now, potential S-genes have been characterized mainly in Arabidopsis (Table 2). To exploit $\mathrm{S}$-genes for resistance breeding, two questions need to be addressed: (1) are there S-gene orthologues across cultivated plant species? and (2) how to obtain and apply loss-of-function mutants of S-genes in resistance breeding? A targeted approach based on comparative genetics/genomics would provide answers to these questions. Firstly, sequence homology to characterized S-genes should be identified by, for example, mining available sequence databases in a certain plant species. Secondly, the potential S-gene candidates should be functionally characterized by gene-silencing techniques such as virus-induced gene silencing (VIGS) and/or RNA interference (RNAi) to observe altered phenotypes for susceptibility to a certain pathogen as well as other agricultural traits. VIGS is a transient gene knocking out, which can be performed nowadays in many plant species for a large-scale functional analysis (Ratcliff et al. 2001; Liu et al. 2002; Hileman et al. 2005; Burch-Smith et al. 2006). To obtain stable-silencing effect, RNAi can be performed (reviewed by Waterhouse and Helliwell 2003). Once the function of a S-gene is confirmed, loss-of-function mutations of the S-gene can be achieved by insertional mutagenesis (Krysan et al. 1999; Parinov et al. 1999; Speulman et al. 1999) and TILLING (targeting induced local lesions in genomes) (Colbert et al. 2001). The application of TILLING is particularly promising, as it combines high efficiency in the identification of mutations of interest with the advantage of being a nontransgenic technology. Alternatively, natural S-gene alleles, which can be obtained by screening genetic resource of a certain plant species and are insensitive to effector manipulation but yet retain their intrinsic function, would be ideal alleles for recessive resistances.

\section{Conclusions}

In summary, resistance can be achieved in different ways: one of them is by the presence of corresponding R-genes to recognize pathogen effectors and another one is by the absence of S-genes. We refer to genes required for susceptibility as S-genes. In this review, we focused on S-genes encoding effector targets that function as either susceptibility factors or negative defense-regulators (Fig. 1). Loss of function of S-genes will lead to resistance that inherits recessively in normal plants and dominantly in plants of which the S-gene is silenced by using RNAi technique.

In practice, the majority of the resistance breeding programs have aimed to introgress R-genes from wild species into crop plants. Dominant resistance is highly effective and often race specific. In most cases, resistance conferred by R-genes can be overcome by pathogens resulting in outbreaks of large epidemics, which 'burst' the once 'booming' cultivars (Van der Hoorn et al. 2002; Panstruga and Dodds 2009). Repeated boom-and-burst cycles in agriculture continuously force breeders to introduce cultivars with new resistance traits. In contrast to R-genes, it has been shown that loss of function in S-genes often leads to durable and broad-spectrum resistance, such as mlo-based resistance. Thus, exploitation of S-gene alleles, which are insensitive to manipulation by pathogen effectors, provides an alterative breeding strategy that is complementary to the R-gene conferred resistance.

Nonhost resistance has often been proposed to be a unique alternative for host resistance and exploitation of genes for nonhost resistance in breeding requires genetic compatibilities between the host and the nonhost species (Niks and Marcel 2009). As this is the exception rather than the rule, genes for nonhost resistance are rarely used in breeding. Despite its durable and broad-spectrum characters, our knowledge on nonhost resistance is limited. Current studies in understanding the genetic factors and molecular mechanisms underlying plant nonhost resistance bear great potentials for target employment of this valuable trait to control host pathogens (Nürnberger and 
Lipka 2005; Schweizer 2007). To this aspect, this review proposed an alternative breeding strategy for nonhost-like resistance by eliminating plant S-genes. This breeding strategy is expected to result in durable and broad-spectrum resistance that resembles nonhost resistance.

Acknowledgments We thank Dr. RE. Niks and the anonymous referees for critical reading of the manuscript and for valuable comments. Also, we thank Dr. T. Bisseling, Dr. M. Koornneef and Dr. R. Panstruga for helpful discussions on the concept of S-genes.

Open Access This article is distributed under the terms of the Creative Commons Attribution Noncommercial License which permits any noncommercial use, distribution, and reproduction in any medium, provided the original author(s) and source are credited.

\section{References}

Albar L, Bangratz-Reyser M, Hebrard E, Ndjiondjop MN, Jones M, Ghesquiere A (2006) Mutations in the eIF(iso)4G translation initiation factor confer high resistance of rice to rice yellow mottle virus. Plant J 47:417-426

Asai T, Tena G, Plotnikova J, Willmann MR, Chiu WL, Gomez-Gomez L, Boller T, Ausubel FM, Sheen J (2002) MAP kinase signalling cascade in Arabidopsis innate immunity. Nature 415:977-983

Bai Y, van der Hulst R, Bonnema G, Marcel TC, MeijerDekens F, Niks RE, Lindhout P (2005) Tomato defense to Oidium neolycopersici: dominant $\mathrm{Ol}$ genes confer isolatedependent resistance via a different mechanism than recessive ol-2. Mol Plant Microbe Interact 18:354-362

Bai Y, Pavan S, Zheng Z, Zappel NF, Reinstadler A, Lotti C, De Giovanni C, Ricciardi L, Lindhout P, Visser R, Theres K, Panstruga R (2008) Naturally occurring broad-spectrum powdery mildew resistance in a Central American tomato accession is caused by loss of mlo function. Mol Plant Microbe Interact 21:30-39

Bari R, Jones JDG (2009) Role of plant hormones in plant defense responses. Plant Mol Biol 69:473-488

Bhat RA, Miklis M, Schmelzer E, Schulze-Lefert P, Panstruga R (2005) Recruitment and interaction dynamics of plant penetration resistance components in a plasma membrane microdomain. Proc Natl Acad Sci USA 102:3135-3140

Bittel P, Robatzek S (2007) Microbe-associated molecular patterns (MAMPs) probe plant immunity. Curr Opin Plant Biol 10:335-341

Boller T, He SY (2009) Innate immunity in plants: an arms race between pattern recognition receptors in plants and effectors in microbial pathogens. Science 324:742-744

Bowling SA, Clarke JD, Liu Y, Klessig DF, Dong X (1997) The cpr5 mutant of Arabidopsis expresses both NPR1dependent and NPR1-independent resistance. Plant Cell 9:1573-1584
Bruce TJA, Pickett JA (2007) Plant defense signaling induced by biotic attacks. Curr Opin Plant Biol 10:387-392

Burch-Smith TM, Schiff M, Liu Y, Dinesh-Kumar SP (2006) Efficient virus-induced gene silencing in Arabidopsis. Plant Physiol 142:21-27

Büschges R, Hollricher K, Panstruga R, Simons G, Wolter M, Frijters A, van Daelen R, van der Lee T, Diergaarde P, Groenendijk J, Topsch S, Vos P, Salamini F, SchulzeLefert P (1997) The barley Mlo gene: a novel control element of plant pathogen resistance. Cell 88:695-705

Caillaud MC, Lecomte P, Jammes F, Quentin M, Pagnotta S, Andrio E, Aleida Engler JD, Marfaing N, Gounon P, Abad P, Favery B (2008) MAP65-3 microtubule-associated protein is essential for nematode-induced giant cel ontogenesis in Arabidopsis. Plant Cell 20:423-437

Candresse T, Le Gall O, Maisonneuve B, German-Retana S, Redondo E (2002) The use of green fluorescent proteintagged recombinant viruses to test lettuce mosaic virus resistance in lettuce. Phytopathology 92:169-176

Chisholm ST, Coaker G, Day B, Staskawicz BJ (2006) Hostmicrobe interactions: shaping the evolution of the plant immune response. Cell 124:803-814

Chu Z, Yuan M, Yao J, Ge X, Yuan B, Xu C, Li X, Fu B, Li Z, Bennetzen JL, Zhang Q, Wang S (2006) Promoter mutations of an essential gene for pollen development result in disease resistance in rice. Genes Dev 20:1250-1255

Clough SJ, Fengler KA, Yu IC, Lippok B, Smith RK Jr, Bent AF (2000) The Arabidopsis dndl "defense, no death" gene encodes a mutated cyclic nucleotide-gated ion channel. Proc Natl Acad Sci USA 97:9323-9328

Colbert T, Till BJ, Tompa R, Reynolds S, Steine MN, Yeung AT, McCallum CM, Comai L, Henikoff S (2001) Highthroughput screening for induced point mutations. Plant Physiol 126:480-484

Consonni C, Humphry ME, Hartmann HA, Livaja M, Durner J, Westphal L, Vogel J, Lipka V, Kemmerling B, SchulzeLefert P, Somerville SC, Panstruga R (2006) Conserved requirement for a plant host cell protein in powdery mildew pathogenesis. Nat Genet 38:716-720

De Almeida Engler J, Favery B, Engler G, Abad P (2005) Loss of susceptibility as an alternative for nematode resistance. Curr Opin Biotechnol 16:112-117

Diaz-Pendon JA, Truniger V, Nieto C, Garcia-Mas J, Bendahmane A, Aranda MA (2004) Advances in understanding recessive resistance to plant viruses. Mol Plant Pathol 5:223-233

Dietrich RA, Delaney TP, Uknes SJ, Ward ER, Ryals JA, Dangl JL (1994) Arabidopsis mutants simulating disease resistance response. Cell 77:565-577

Du L, Ali GS, Simons KA, Hou J, Yang T, Reddy ASN, Poovaiah BW (2009) Ca2+/calmodulin regulates salicylicacid-mediated plant immunity. Nature 457:1154-1158

Eckardt NA (2002) Plant disease susceptibility genes? Plant Cell 14:1983-1986

Elliot C, Zhou F, Spielmeyer W, Panstruga R, Schulze-Lefert P (2002) Functional conversation of wheat and rice Mlo orthologs in defense modulation to powdery mildew fungus. Mol Plant Microbe Interact 15:1069-1077

Ellis J (2006) Insights into nonhost disease resistance: can they assist disease control in agriculture? Plant Cell 18: $523-528$ 
Ellis C, Karafyllidis I, Wasternack C, Turner JG (2002) The Arabidopsis mutant cevl links cell wall signaling to jasmonate and ethylene responses. Plant Cell 14:1557-1566

Ellis C, Turner JG (2001) The Arabidopsis mutant cev1 has constitutively active jasmonate and ethylene signal pathways and enhanced resistance to pathogens. Plant Cell 13:1025-1033

Eulgem T, Somssich IE (2007) Networks of WRKY transcription factors in defense signaling. Curr Opin Plant Biol 10:366-371

Feechan A, Jermakow AM, Torregrosa L, Panstruga R, Dry B (2008) Identification of grapevine MLO gene candidates involved in susceptibility to powdery mildew. Funct Plant Biol 35:1255-1266

Fondevilla S, Carver TLW, Moreno MT, Rubiales D (2006) Macroscopic and histological characterization of genes er 1 and $e r 2$ for powdery mildew resistance in pea. Eur $\mathbf{J}$ Plant Pathol 115:309-321

Friesen TL, Faris JD, Solomon PS, Oliver RP (2008) Hostspecific toxins: effectors of necrotrophic pathogenicity. Cell Microbiol 10:1421-1428

Frye CA, Tang D, Innes RW (2001) Negative regulation of defense responses in plants by a conserved MAPKK kinase. Proc Natl Acad Sci USA 98:373-378

Gao Z, Eyers S, Thomas C, Ellis N, Maule A (2004a) Identification of markers tightly linked to $\mathrm{sbm}$ recessive genes for resistance to Pea seed-borne mosaic virus. Theor Appl Genet 109:488-494

Gao Z, Johansen E, Eyers S, Thomas CL, Noel Ellis TH, Maule AJ (2004b) The potyvirus recessive resistance gene, sbml, identifies a novel role for translation initiation factor eIF4E in cell-to-cell trafficking. Plant J 40:376-385

Gao X, Starr J, Gobel C, Engelberth J, Feusser I, Tumlinson J, Kolomiets M (2008) Maize 9-lipoxygenase ZmLOX3 controls development, root-specific expression of defense genes, and resistance to root-knot nematodes. Mol Plant Microbe Interact 21:98-109

Hardham AR, Jones DA, Takemoto D (2007) Cytoskeleton and cell wall function in penetration resistance. Curr Opin Plant Biol 10:342-348

Heath M (2000) Nonhost resistance and nonspecific plant defenses. Curr Opin Plant Biol 3:315-319

Hileman LC, Drea S, Martino G, Litt A, Irish VF (2005) Virusinduced gene silencing is an effective tool for assaying gene function in the basal eudicot species Papaver somniferum (opium poppy). Plant J 44:334-341

Hoefle C, Hückelhoven R (2008) Enemy at the gates: traffic at the plant cell pathogen interface. Cell Microbiol 10: 2400-2407

Hückelhoven R (2005) Powdery mildew susceptibility and biotrophic infection strategies. FEMS Microbiol Lett 245:9-17

Humphry M, Consonni C, Panstruga R (2006) mlo-based powdery mildew immunity: silver bullet or simply nonhost resistance? Mol Plant Pathol 7:605-610

Iyer-Pascuzzi AS, McCouch SR (2007) Recessive resistance genes and the Oryza sativa-Xanthomonas oryzae pv. oryzae pathosystem. Mol Plant Microbe Interact 20:731-739

Jones JD, Dangl JL (2006) The plant immune system. Nature 444:323-329

Jurkowski GI, Smith RK Jr, Yu IC, Ham JH, Sharma SB, Klessig DF, Fengler KA, Bent AF (2004) Arabidopsis
DND2, a second cyclic nucleotide-gated ion channel gene for which mutation causes the "defense, no death" phenotype. Mol Plant Microbe Interact 17:511-520

Kachroo P, Shanklin J, Shah J, Whittle EJ, Klessig DF (2001) A fatty acid desaturase modulates the activation of defense signaling pathways in plants. Proc Natl Acad Sci USA 98:9448-9453

Kaminaka H, Nake C, Epple P, Dittgen J, Schutze K, Chaban C, Holt BFIII, Merkle T, Schafer E, Harter K, Dangl JL (2006) bZIP10-LSD1 antagonism modulates basal defense and cell death in Arabidopsis following infection. EMBO J 25:4400-4411

Kamoun S (2007) Groovy times: filamentous pathogen effectors revealed. Curr Opin Plant Biol 10:358-365

Kang BC, Yeam I, Frantz JD, Murphy JF, Jahn MM (2005a) The pvrl locus in Capsicum encodes a translation initiation factor eIF4E that interacts with Tobacco etch virus VPg. Plant J 42:392-405

Kang BC, Yeam I, Jahn MM (2005b) Genetics of plant virus resistance. Annu Rev Phytopathol 43:581-621

Kay S, Hahn S, Marois E, Hause G, Bonas U (2007) A bacterial effector acts as a plant transcription factor and induce a cell size regulator. Science 318:648-651

Kim HS, Delaney TP (2002) Arabidopsis SON1 is an F-box protein that regulates a novel induced defense response independent of both salicylic acid and systemic acquired resistance. Plant Cell 14:1469-1482

Kirik V, Bouyer D, Schobinger U, Bechtold N, Herzog M, Bonneville JM, Hulskamp M (2001) CPR5 is involved in cell proliferation and cell death control and encodes a novel transmembrane protein. Curr Biol 11:1891-1895

Krysan PJ, Young JC, Sussman MR (1999) T-DNA as an insertional mutagen in Arabidopsis. Plant Cell 11:22832290

Li X, Zhang Y, Clarke JD, Li Y, Dong X (1999) Identification and cloning of a negative regulator of systemic acquired resistance, SNI1, through a screen for suppressors of npr1-1. Cell 98:329-339

Lipka V, Dittgen J, Bednarek P, Bhat R, Wiermer M, Stein M, Landtag J, Brandt W, Rosahl S, Scheel D, Llorente F, Molina A, Parker J, Somerville S, Schulze-Lefert P (2005) Pre- and postinvasion defenses both contribute to nonhost resistance in Arabidopsis. Science 310:1180-1183

Lipka U, Fuchs R, Lipka V (2008) Arabidopsis non-host resistance to powdery mildews. Curr Opin Plant Biol 11:404-411

Liu Y, Schiff M, Dinesh-Kumar SP (2002) Virus-induced gene silencing in tomato. Plant J 31:777-786

Lyngkjaer MF, Newton AC, Atzema JL, Baker SJ (2000) The barley mlo-gene: an important powdery mildew resistance source. Agronomie 20:745-756

Morales M, Orjeda G, Nieto C, van Leeuwen H, Monfort A, Charpentier M, Caboche M, Arus P, Puigdomenech P, Aranda MA, Dogimont C, Bendahmane A, Garcia-Mas J (2005) A physical map covering the nsv locus that confers resistance to Melon necrotic spot virus in melon (Cucumis melo L.). Theor Appl Genet 111:914-922

Mosher RA, Durrant WE, Wang D, Song J, Dong X (2006) A comprehensive structure-function analysis of Arabidopsis SNI1 defines essential regions and transcriptional repressor activity. Plant Cell 18:1750-1765 
Nicaise V, German-Retana S, Sanjuan R, Dubrana MP, Mazier M, Maisonneuve B, Candresse T, Caranta C, LeGall O (2003) The eukaryotic translation initiation factor 4E controls lettuce susceptibility to the Potyvirus Lettuce mosaic virus. Plant Physiol 132:1272-1282

Nieto C, Morales M, Orjeda G, Clepet C, Monfort A, Sturbois B, Puigdomenech P, Pitrat M, Caboche M, Dogimont C, Garcia-Mas J, Aranda MA, Bendahmane A (2006) An eIF4E allele confers resistance to an uncapped and nonpolyadenylated RNA virus in melon. Plant J 48:452-462

Niks RE, Marcel TC (2009) Nonhost resistance and basal resistance: how to explain specificity? New Phytol 182: $817-828$

Nishimura MT, Stein M, Hou BH, Vogel JP, Edwards H, Somerville SC (2003) Loss of a callose synthase results in salicylic acid-dependent disease resistance. Science 301: 969-972

Nomura K, Melotto M, He SY (2005) Suppression of host defense in compatible plant-Pseudomonas syringae interactions. Curr Opin Plant Biol 8:361-368

Nürnberger T, Lipka V (2005) Non-host resistance in plants: new insights into an old phenomenon. Mol Plant Pathol 6:335-345

Oh SK, Baek KH, Park JM, Yi SY, Yu SH, Kamoun S, Choi D (2008) Capsicum annuum WRKY protein CaWRKY1 is a negative regulator of pathogen defense. New Phytol 177: 977-989

Panstruga R (2005) Serpentine plant MLO proteins as entry portals for powdery mildew fungi. Biochem Soc Trans 33:389-392

Panstruga R, Dodds PN (2009) Terrific protein traffic: the mystery of effector protein delivery by filamentous plant pathogens. Science 324:748-750

Parinov S, Sevugan M, Ye D, Yang WC, Kumaran M, Sundaresan V (1999) Analysis of flanking sequences from dissociation insertion lines: a database for reverse genetics in Arabidopsis. Plant Cell 11:2263-2270

Pavan S, Zheng Z, van den Berg P, Lotti C, De Giovanni C, Borisova M, Lindhout P, de Jong H, Ricciardi L, Visser R, Bai Y (2008) Map- vs homology-based cloning for the recessive gene ol-2 conferring resistance to tomato powdery mildew. Euphytica 162:91-98

Peng Y, Bartley LE, Chen X, Dardick C, Chern M, Ruan R, Canlas PE, Ronald PC (2008) OsWRKY62 is a Negative Regulator of Basal and Xa21-Mediated Defense against Xanthomonas oryzae pv. Oryzae in Rice. Mol Plant $1: 446-458$

Petersen M, Brodersen P, Naested H, Andreasson E, Lindhart U, Johansen B, Nielsen HB, Lacy M, Austin MJ, Parker JE, Sharma SB, Klessig DF, Martienssen R, Mattsson O, Jensen AB, Mundy J (2000) Arabidopsis map kinase 4 negatively regulates systemic acquired resistance. Cell 103:1111-1120

Piffanelli P, Ramsay L, Waugh R, Benabdelmouna A, D'Hont A, Hollricher K, Jorgensen JH, Schulze-Lefert P, Panstruga R (2004) A barley cultivation-associated polymorphism conveys resistance to powdery mildew. Nature 430:887-891

Rakotomalala M, Pinel-Galzi A, Albar L, Ghesquiere A, Rabenantoandro Y, Ramavovololona P, Fargette D (2008)
Resistance to rice yellow mottle virus in rice germplasm in Madagascar. Eur J Plant Pathol 122:277-286

Ratcliff F, Martin-Hernandez AM, Baulcombe DC (2001) Technical advance. Tobacco rattle virus as a vector for analysis of gene function by silencing. Plant $\mathrm{J} 25$ : 237-245

Robaglia C, Caranta C (2006) Translation initiation factors: a weak link in plant RNA virus infection. Trends Plant Sci 11:40-45

Robert-Seilaniantz A, Navarro L, Bari R, Jones JDG (2007) Pathological hormone imbalances. Curr Opin Plant Biol 10:372-379

Schulze-Lefert P, Vogel J (2000) Closing the ranks to attack by powdery mildew. Trends Plant Sci 5:343-347

Schweizer P (2007) Nonhost resistance to powdery mildewnew opportunities to unravel the mystery. Physiol Mol Plant Pathol 70:3-7

Shah J, Kachroo P, Nandi A, Klessig DF (2001) A recessive mutation in the Arabidopsis SSI2 gene confers SA- and NPR1-independent expression of PR genes and resistance against bacterial and oomycete pathogens. Plant $\mathrm{J} 25$ : 563-574

Shang Y, Li X, Cui H, He P, Thilmony R, Chintamanani S, Zwiesler-Vollick J, Gopalan S, Tang X, Zhou JM (2006) RAR1, a central player in plant immunity, is targeted by Pseudomonas syringae effector AvrB. Proc Natl Acad Sci USA 103:19200-19205

Shen QH, Saijo Y, Mauch S, Biskup C, Bieri S, Keller B, Seki H, Ulker B, Somssich IE, Schulze-Lefert P (2007) Nuclear activity of MLA immune receptors links isolatespecific and basal disease-resistance responses. Science 315:1098-1103

Singh DP, Singh A (2005) Disease and insect resistance in Plant. Page 104. ISBN 978-1-57808-412-8. Science, Enfiel

Speth EB, Lee YN, He SY (2007) Pathogen virulence factors as molecular probes of basic plant cellular functions. Curr Opin Plant Biol 10:580-586

Speulman E, Metz PL, van Arkel G, te Lintel Hekkert B, Stiekema WJ, Pereira A (1999) A two-component enhancer-inhibitor transposon mutagenesis system for functional analysis of the Arabidopsis genome. Plant Cell 11:1853-1866

Stein M, Somerville SC (2002) MLO, a novel modulator of plant defenses and cell death, binds calmodulin. Trends Plant Sci 7:379-380

Stubbs RW, Sanders M, Zeven AC (1983) A recessive resistance gene for yellow rust (Puccinia striiformis West.) in bread wheat (Triticum aestivum L.). Euphytica 33: $561-562$

Sugio A, Yang B, Zhu T, White FF (2007) Two type III effector genes of Xanthomonas oryzae pv. oryzae control the induction of the host genes OsTFIIAgammal and OsTFX1 during bacterial blight of rice. Proc Natl Acad Sci USA 104:10720-10725

Sweat TA, Lorang JM, Bakker EG, Wolpert TJ (2008) Characterization of natural and induced variation in the LOVI gene, a CC-NB-LRR gene conferring victorin sensitivity and disease susceptibility in Arabidopsis. Mol Plant Microbe Interact 21:7-19 
Takken FA, Albrecht M, Tameling WIL (2006) Resistance proteins: molecular switches of plant defense. Curr Opin Plant Biol 9:383-390

Tang D, Christiansen KM, Innes RW (2005) Regulation of plant disease, stress responses, cell death, and ethylene signaling in Arabidopsis by EDR1 protein kinase. Plant Physiol 138:1018-1026

Thordal-Christensen H (2003) Fresh insights into processes of nonhost resistance. Curr Opin Plant Biol 6:351-357

Trujillo M, Troeger M, Niks RE, Kogel KH, Hückelhoven R (2004) Mechanistic and genetic overlap of barley host and non-host resistance to Blumeria graminis. Mol Plant Pathol 5:389-396

Tsujimoto Y, Numaga T, Ohshima K, Yano MA, Ohsawa R, Goto DB, Naito S, Ishikawa M (2003) Arabidopsis TOBAMOVIRUS MULTIPLICATION (TOM) 2 locus encodes a transmembrane protein that interacts with TOM1. EMBO J 22:335-343

Tyrka M, Perovic D, Wardynska A, Ordon F (2008) A new diagnostic SSR marker for selection of the Rym4/Rym5 locus in barley breeding. J Appl Genet 49:127-134

Van Damme M (2007) Genetic analysis of disease susceptibility in the Arabidopsis-Hyaloperonospora parasitica interaction. $\mathrm{PhD}$ thesis, University of Utrecht, The Netherlands

Van Damme M, Andel A, Huibers RP, Panstruga R, Weisbeek PJ, Van den Ackerveken G (2005) Identification of Arabidopsis loci required for susceptibility to the downy mildew pathogen Hyaloperonospora parasitica. Mol Plant Microbe Interact 18:583-592

Van Damme M, Huibers RP, Elberse J, Van den Ackerveken G (2008) Arabidopsis DMR6 encodes a putative 2OG-Fe(II) oxygenase that is defense-associated but required for susceptibility to downy mildew. Plant J 54:785-793

Van der Hoorn RAL, Kamoun S (2008) From guardee to decoy: a new model for perception of plant pathogen effectors. Plant Cell 20:2009-2017

Van der Hoorn RAL, De Wit PJ, Joosten MH (2002) Balancing selection favors guarding resistance proteins. Trends Plant Sci 7:67-71

Veronese P, Nakagami H, Bluhm B, Abuqamar S, Chen X, Salmeron J, Dietrich RA, Hirt H, Mengiste T (2006) The membrane-anchored BOTRYTIS-INDUCED KINASE1 plays distinct roles in Arabidopsis resistance to necrotrophic and biotrophic pathogens. Plant Cell 18:257-273

Vogel J, Somerville S (2000) Isolation and characterization of powdery mildew-resistant Arabidopsis mutants. Proc Natl Acad Sci USA 97:1897-1902

Vogel JP, Raab TK, Schiff C, Somerville SC (2002) PMR6, a pectate lyase-like gene required for powdery mildew susceptibility in Arabidopsis. Plant Cell 14:2095-2106

Vogel JP, Raab TK, Somerville CR, Somerville SC (2004) Mutations in PMR5 result in powdery mildew resistance and altered cell wall composition. Plant J 40:968-978

Waterhouse PM, Helliwell CA (2003) Exploring plant genomes by RNA-induced gene silencing. Nat Rev Genet 4:29-38

Wladimir I, Tameling L, Takken FLW (2008) Resistance proteins: scout of the plant innate immune system. Eur J Plant Pathol 121:243-255

Wolpert TJ, Dunkle LD, Ciuffetti LM (2002) Host-selective toxins and avirulence determinants: what's in a name? Annu Rev Phytopathol 40:251-285

Xing DH, Lai ZB, Zheng ZY, Vinod KM, Fan BF, Chen ZX (2008) Stress- and pathogen-induced Arabidopsis WRKY48 is a transcriptional activator that represses plant basal defense. Mol Plant 1:459-470

Yan GP, Chen XM (2006) Molecular mapping of a recessive gene for resistance to stripe rust in barley. Theo and Appl Gene 113:529-537

Yang B, Sugio A, White FF (2006) Os $8 N 3$ is a host diseasesusceptibility gene for bacterial blight of rice. Proc Natl Acad Sci USA 103:10503-10508

Yu IC, Parker J, Bent AF (1998) Gene-for-gene disease resistance without the hypersensitive response in Arabidopsis dnd1 mutant. Proc Natl Acad Sci USA 95:7819-7824

Zhang J, Shao F, Li Y, Cui HT, Chen L, Li H, Zou Y, Long C, Lan L, Chai J, Chen S, Tang X, Zhou JM (2007) A Pseudomonas syringae effector inactivates MAPKs to suppress PAMP-induced immunity in plants. Cell Host Microbe 1:175-185

Zhou JM, Chai J (2008) Plant pathogen bacterial type III effectors subdue host responses. Curr Opin Microbiol 11:179-185 